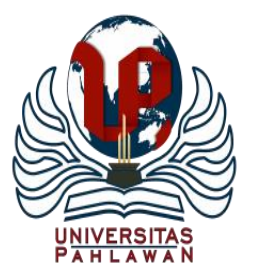

Jurnal Basicedu Volume 5 Nomor 1 Tahun 2021 Halaman 47-64

JURNAL BASICEDU

Research \& Learning in Elementary Education

https://jbasic.org/index.php/basicedu

\title{
Pengembangan Media Pembelajaran Mobile Learning Berbasis Android pada Konsep Sistem Peredaran Darah di Sekolah Dasar
}

\author{
Milda Asti Widiastika ${ }^{1}$, Nana Hendracipta ${ }^{2}$, A. Syachruroji ${ }^{3}$ \\ Universitas Sultan Ageng Tirtayasa, Indonesia ${ }^{1,2,3}$ \\ E-mail : $\underline{\text { milda825aw@gmail.com }{ }^{1}} \underline{\text { nanahendracipta@ untirta.ac.id }} \underline{\text { ahmadsyachruroji@ untirta.ac.id }}^{3}$
}

\begin{abstract}
Abstrak
Penelitian ini didasari oleh minimnya penggunaan media pembelajaran saat proses pembelajaran yang dilakukan oleh guru, sehingga siswa menjadi jenuh dan kurang memahami konsep yang diajarkan. Penelitian ini bertujuan untuk mengetahui kelayakan media pembelajaran mobile learning berbasis android, pemahaman konsep anak didik setelah menggunakan media pembelajaran mobile learning berbasis android, dan respon anak didik terhadap penggunaan media pembelajaran mobile learning berbasis android. Metode penelitian yang digunakan pada metode penelitian pengembangan (Research and Development) dari Borg and Gall yang terdiri 6 tahapan yaitu analisis masalah, pengumpulan data, desain produk, validasi/uji ahli, revisi produk dan uji coba produk (uji skala terbatas). Penelitian ini dilakukan di SDN Taman Baru 1 dengan subjek penelitian di kelas V dengan 25 anak didik pada uji coba terbatas dengan menggunakan instrument berupa lembar angket validasi ahli, soal pertanyaan sebanyak 5 butir soal dan angket respon anak didik. Hasil uji validasi oleh ahli memperoleh rata-rata skor $84 \%$ yang termasuk dalam kategori "Sangat Layak". Pemahaman konsep anak didik setelah menggunakan media didapatkan dari hasil skor pretest dan posttest yang dihitung yakni sebesar 0,8 dengan kategori "Tinggi". Respon anak didik terhadap penggunaan media pembelajaran dengan rata-rata skor $83,8 \%$ dengan kategori "Sangat Baik".
\end{abstract}

Kata kunci: IPA, mobile learning, android

\section{Abstract}

The background is on the lack use of the learning media during learning process conducted by teachers, so students feel uninterested and less understanding of the learning concept. This research aims to find out the validity of android-based mobile learning media, understanding the students' concept after using androidbased mobile learning media, and students' responses to the use of android-based mobile learning media. This research is using the Research and Development method, referring to Borg and Gall's development model consisted of 6 stages of development processes, namely problems' analysis, data collection, product design, validation, product revisions, and product trials test (limited scale trials). The study conducted at SDN Taman Baru 1 with taken the fifth-grade students as subjects consisted of 25 students to accomplished the limited trial testusing instruments in the form of expert validation questionnaires, 5 questions and student response questionnaires. The validation test results by the experts obtained an average score of $84 \%$ with a very worthy category. The understanding students' concept after using the learning media obtained from pretest and post-test scores calculated of 0,8 included in the high indicator. Students' responses to the use learning media gained an average score of $83,8 \%$ with a very worthy category.

Keywords: science, mobile learning, android

Copyright (c) 2021 Milda Asti Widiastika, Nana Hendracipta, A. Syachruroji

$\triangle$ Corresponding author

Address : Cilegon, Banten

ISSN 2580-3735 (Media Cetak)

Email : milda825aw@gmail.com

ISSN 2580-1147 (Media Online)

Phone : 082210557866

DOI : https://doi.org/10.31004/basicedu.v5i1.602 


\section{PENDAHULUAN}

Perkembangan teknologi saat ini memang sudah tidak dipungkiri lagi, kini semakin banyak anak didik sekolah dasar yang sudah difasilitasi Smartphone atau telepon genggam oleh orang tuanya, akan tetapi kebanyakan anak didik sekolah dasar tersebut memanfaatkan smartphone tersebut hanya untuk bermain game, menonton video di youtube juga bermain sosial media saja. Smartphone adalah telepon genggam yang mempunyai keunggulan yaitu kemampuan multitasking yang memudahkan pengguna mengerjakan tugas lebih dari satu dalam satu waktu.

Kini perkembangan teknologi pun semakin menggerakkan timbulnya perubahan di seluruh aspek. Salah satunya adalah bidang edukasi yang bercirikan komunikasi digital. Menurut (Istiyanto, 2013:1) "komunikasi digital nirkabel sudah sangat dibutuhkan pada berbagai bidang, seperti edukasi, bisnis, hiburan, kesehatan atau keamanan, sehingga sangat diperlukan ketersediaan perangkat mobile yang dapat mendukung aktivitas penggunaan di berbagai lingkungan dengan fleksibilitas tinggi, perangkat yang lebih praktis dalam penggunaan”. Perkembangan teknologi di bagian edukasi bisa dilihat dalam penggunaan perlengkapan media pembelajaran yang ditandai terbentuknya konsep E-Learning.

Berdasarkan pengisian kuesioner tentang kepemilikan smartphone pada anak didik di kelas V SDN Taman Baru I terdapat 20 dari 25 anak didik sudah memiliki smartphone. Mereka menggunakan smartphone untuk mencari materi tambahan ataupun tugas yang diperintahkan oleh guru saat dirumah. Selain itu juga mereka menggunakan smartphone mereka untuk membuka sosial media seperti Instagram, Youtube, Whatsapp, hingga TikTok. Mereka diizinkan membawa smartphone ke sekolah hanya untuk berkomunikasi dengan orang tua karna jarak sekolah dengan rumah anak didik yang cukup jauh dengan syarat smartphone anak didik saat jam pelajaran dimatikan atau dititipkan kepada wali kelas mereka.

Sistem operasi android saat ini dengan kecepatan yang sangat spektakuler telah tumbuh dengan pesat. Kejayaan android tidak lepas dari sifatnya yang terbuka, yang menyodorkan kode sumber perangkat lunak secara percuma sehingga para pengembang dapat mengembangkan, mengedarkan dan mengadakannya tanpa membayar lisensi. Selain itu android menyediakan aplikasi berbayar maupun yang gratis dari pengembang android sehingga mempermudah pemakai android. Android dapat dimanfaatkan untuk pembelajaran IPA.

Beberapa materi IPA tidak dapat dilihat langsung secara kesat mata dan terjadinya secara fisiologis, salah satunya materi sistem peredaran darah. Berdasarkan hasil wawancara tidak terstruktur sebelumnya dilakukan kepada wali kelas V SDN Taman Baru 1 menunjukkan bahwa masih terdapat anak didik yang belum mencapai ketuntasan (KKM) dan hal itu terbukti dari hasil pretest yang peneliti berikan dengan rentan nilai 35-70 dan rara-rata 52,6. Berdasarkan hasil wawancara tidak terstruktur yang sebelumnya dilakukan terhadap wali kelas V di SDN Taman Baru 1 bahwa ada beberapa jumlah masalah yang 
ditemukan dikelas V Tahun Ademik 2019/2020 seperti anak didik kurang mengetahui dan memahami organ dalam sistem peredaran darah, anak didik kurang mampu dalam memahaminya bagaimana proses-proses yang terjadi pada sistem peredaran darah, permasalahan hal tersebut terlihat dari ketuntasan anak didik yang kurang mencapai standar yang telah ditentukan yakni sebanyak 15 dari 25 anak didik.

Berdasarkan hasil observasi terlihat kendala dalam hal penggunaan media yang belum dapat meningkatkan pemahaman anak didik, itu disebabkan karena guru hanya menggunakan media yang kurang bervariasi, dan terkesan monoton juga guru tidak melakukan inovasiinovasi dan kreativitas dalam proses belajar seperti cuma memanfaatkan buku pelajaran yang sudah disediakan oleh pihak sekolah untuk dijadikan sebagai media dan sumber penuh dalam proses pembelajaran dan akhirnya membuat anak didik jenuh dan culas untuk memahami konsep yang telah disampaikan.

Mobile learning berbasis android ini berisikan uraian atau materi, soal latihan dan pembahasan hingga game tentang konsep sistem peredaran darah mata pelajaran IPA kelas 5 yang tersusun secara sistematis agar mempermudahkan anak didik dalam mencari informasi mengenai sistem peredaran darah tersebut. Mobile learning berbasis android pada konsep sistem peredaran darah diharapkan dapat menjadi bahan penunjang pembelajaran guru di dalam kelas agar pembelajaran dapat lebih variatif sekaligus memudahkan anak didik memahami konsep pada saat proses pembelajaran.
Berangkat dari hal tersebut mobile learning berbasis android pada konsep sistem peredaran darah adalah suatu produk yang mempunyai tujuan mengetahui kelayakan media pembelajaran mobile learning berbasis android, pemahaman konsep anak didik setelah menggunakan media pembelajaran mobile learning berbasis android, dan respon anak didik terhadap penggunaan media pembelajaran mobile learning berbasis android.

Media pembelajaran adalah perangkat atau suatu alat berupa gambar, suara, dan audiovisual yang membantu meringankan dan mempermudah pemahaman anak didik dan guru untuk menangkap materi ajar yang akan disampaikan serta memberi gambaran nyata atau real guna mempertajam pemahaman anak didik mengenai materi yang disampaikan. Menurut (Daryanto, 2010:12) media pembelajaran adalah seluruh objek baik manusia, benda bahkan lingkungan sekitar yang dapat dijadikan sarana untuk mengantarkan atau meneruskan pesan dalam pembelajaran sehingga dapat membangkitkan ketertarikan, keinginan, daya pikir dan perasaan anak didik pada kegiatan belajar untuk menggapai tujuan.

Tanggapan (Jamaludin \& Rachmatullah, 2018:125) dalam kegiatan mengajar yang dilakukan oleh pendidik media pembelajaran memiliki fungsi sebagai berikut: (1) sebagai sarana pembantu, (2) sebagai sumber belajar, (3) memikat perhatian anak didik, (4) memperlaju proses belajar mengajar, (5) menaikkan mutu atau kualitas belajar.

Menurut (Sutikno \& Fathurrohman, 2010:67) macam-macam media dilihat dari jenisnya, media dibagi kedalam media auditif, 
media visual dan media audiovisual. Tanggapan Rudy Brets (Sanjaya, 2012:212), klasifikasi media, yaitu: (1) Media gerak audiovisual, semacam: film bersuara, kaset video, film televisi. (2) Media semi bergerak, semacam: huruf jangkauan jauh. (3) Media visual bergerak, semacam: film bisu. (4) Media visual tidak bersuara, semacam: halaman tercetak, foto, mikrofon, slide tanpa suara. (5) Media audio, semacam: radio, televisi, pita radio (6) Media cetak, semacam: buku, modul, bahan ajar mandiri.

Mobile learning dijelaskan sebagai edukasi yang dilakukan dengan menggunakan perangkat tanpa kabel semacam handphone, personal digital assistans (PDAs), atau laptop (O’Malley et al., 2005:7). Mobile learning adalah pilihan dimana layanan pembelajaran harus bisa dilakukan dimana dan kapanpun (Darmawan, 2011:15). Klasifikasi M-Learning yaitu berdasarkan: (1) Jenis perangkat yang digunakan. (2) Menggunakan teknologi nirkabel. (3) Jenis informasi yang dapat diakses. (4) Jenis akses (daring/luring). (5) Lokasi. (6) Jenis komunikasi (7) Dukungan untuk standar $M$ Learning.

(Lee, 2012:2) android adalah sistem operasi seluler yang memodifikasi Linux. Awal dikembangkan dengan nama yang sama, yaitu Android inc. Pada 2005 google menengok berapa banyak pengguna daring menggunakan perangkat seluler dan melihat masa depan yang cerah untuk dunia seluler jadi google membeli android dan mulai mengembangkannya. Tanggapan (Seng, 2011:4) kemajuan android makin cepat dan stabil merilis terbitan baru untuk menyenangkan pengguna dan bahkan sekarang posisis android dapat melampaui kemajuan 30 Windows ataupun Apple.

Berikut ini adalah beberapa perkembangan versi dari android: (1) Android 1.0 Apple Pie dimunculkan 23 September 2008. (2) Android 1.1 Banana Bread dimunculkan 9 Februari 2009 (3) Android 1.5 Cupcake dimunculkan 30 April 2009 (4) Android 1.6 Donut dimunculkan 15 September 2009 (5) Android 2.0/2.1 Éclair dimunculkan 26 Oktober 2009 (6) Android 2.2 Froyo dimunculkan 10 Mei 2010 (7) Android 2.3 Gingerbread dimunculkan 6 Desember 2010 (8) Android 3.0/3.1 Honeycomb dimunculkan 22 Februari 2011 (9) Android 4.0 Ice Cream Sandwich dimunculkan 2011 (10) Android 4.1/4.2 Jelly Bean dimunculkan 2013 (11) Android 4.4 KitKat dimunculkan 2014 (12) Android 5.0 Lolipop (13) Android 6.0 Marshmallow dimunculkan Juni 2015 (14) Android 7.0 \& 7.1: Nougat dimunculkan Juni 2016 (15) Android 8.0 \& 8.1: Oreo dimunculkan Agustus 2017.

(TIM EMS, 2015:6-7) memperlihatkan fitur Android sebagai berikut: (1) peluang untuk mengembangkan aplikasi memiliki prospek di dunia industri sebagai seorang pengembang, (2) sederhanakan proses pengembangan aplikasi android dengan berbagai API yang sepenuhnya dapat diakses dan siap digunakan (3) platform terbuka (4) android dapat berjalan dilayar dengan ukuran dan resolusi berbeda.

Menurut (TIM EMS, 2015:7-8) kelebihan android adalah sebagai berikut: (1) multitasking, (2) layar beranda ponsel menampilkan pemberitahuan diikuti dengan indikator atau suara yang berkedip, (3) mendukung ribuan aplikasi 
terverifikasi melalui situs Goole Play, (4) gunakan widget di home screen, untuk mempermudah dan mempercepat dalam membuka aplikasi. Selanjutnya Tanggapan (TIM EMS, 2015:7-8) kelemahan android adalah sebagai berikut: (1) limbah pendayagunaan baterai, (2) konsentrasi Google, karena android merupakan open source dari Google, (3) degan tidak mendukung penggunaan J2ME, ini karena android hanya menggunakan bahasa dan pustaka serta UI berbeda dengan J2ME, (4) keamanan masih lemah. Untuk beberapa vendor antivirus mempersipkan aplikasi antivirus di varian android.

Membuat media edukasi berupa mobile learning berbasis android ini menggunakan software Smart App Creator sebagai software pengembang utama. Smart Apps Creator merupakan software untuk membikin aplikasi mobile android dan ios tanpa kode program dan dapat membuat format HTML5 dan .exe.

Tanggapan (Depdiknas, 2006:124) "pembelajaran IPA di sekolah dasar merupakan ilmu pengetahuan yang tidak hanya penguasaan sekumpulan pengetahuan berupa fakta, konsep, atau prinsip, tetapi juga proses penemuannya. Selama proses pembelajaran lebih ditekankan pada pengalaman langsung dengan tujuan pegembangan kompetensi untuk penelitian ilmiah dan pemahaman tentang lingkungan."

\section{METODE}

Penelitian ini dilakukan di SDN Taman Baru 1 Tahun Ajaran 2019/2020 dimulai dari 02 Maret 2020 s/d 31 Agustus 2020. Desain penelitian pengembangan yang akan ditempuh mengarah pada desain pengembangan yang dilakukan oleh (Sugiyono, 2011:408) yang dimodifikasi meliputi 6 langkah yaitu, Analisis Masalah, Pengumpulan Data, Desain Produk, Validasi / uji Ahli, Revisi Produk dan Uji Coba Produk. Dibawah ini merupakan langkah-langkah dalam penelitian dan pengembangan (R\&D) ditunjukan pada bagan sebagai berikut:

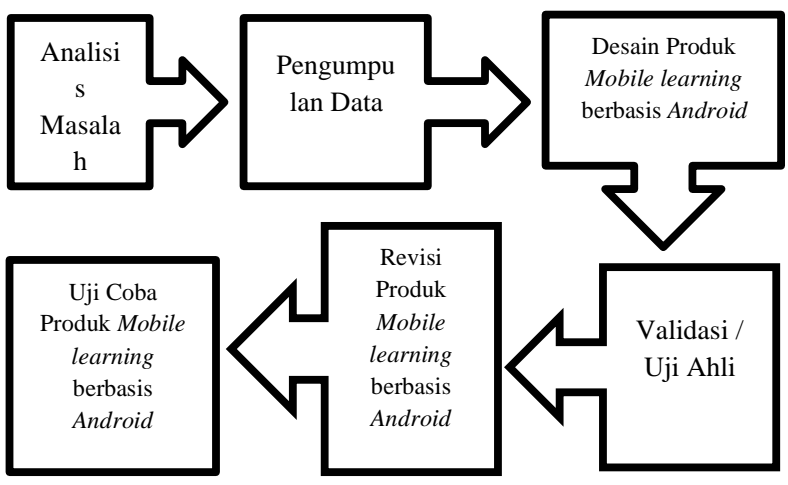

Bagan 1. Alur modifikasi R\&D (Sugiyono, 2011:408).

Penelitian ini diawali dari tahap analisis masalah yang terdiri dari tiga tahap yaitu: (1) analisis kurikulum ini dilakukan untuk menentukan kurikulum yang digunakan disekolah.

(2) Analisis materi ini dilakukan untuk menentukan materi yang masih kurang dipahami oleh anak didik dan akan digunakan dalam pengembangan media mobile learning berbasis android. (3) Analisis kebutuhan yang untuk dijadikan pedoman pengembangan media mobile learning berbasis android.

Tahap pengumpulan data selanjutnya dikumpulkan berbagai informasi dan studi literatur untuk merencanakan pengembangan suatu produk yang dapat menghasilkan suatu bahan ajar yang dapat dimanfaatkan oleh guru dan anak didik. Data 
yang dikumpulkan pada tahap ini berupa studi literatur dari data analisis kurikulum, analisis materi, serta analisis kegiatan belajar mengajar materi sistem peredaran darah untuk analisis kebutuhan mobile learning berbasis android menggunakan kuisioner, wawancara tidak terstruktur pada materi sistem peredaran darah.

Tahap desain produk, desain ini masih bersifat hipotetis. Ini dianggap hipotesis karena efektivitasnya belum terbukti, dan akan diketahui setelah lulus tes. Desain setiap produk harus disajikan pada gambar kerja, pembuatan desain ini meliputi cover, materi, video animasi, soal latihan, profil pengembang, daftar pustaka, KD dan indikator dan glosarium.

Tahap Validasi/uji ahli, sebelum di uji cobakan produk yang telah dikembangkan, harus melewati tahapan validasi (uji ahli) terlebih dahulu. Tujuannya agar mengetahui apakah mobile learning berbasis android tersebut telah memenuhi kriteria atau belum. Uji ahli untuk validasi mobile learning berbasis android ini dilaksanakan dalam 2 kategori, yaitu: (1) ahli media (2) ahli materi. Pada masing-masing ahli tersebut dilakukan oleh 2 orang dosen.

Tahap revisi desain, pada tahapan ini dilakukan revisi dan hasil validasi dari para tim ahli untuk memperbaiki kelemahan-kelemahan. Setelah lulus uji coba akan dimungkinkan untuk mengetahui kelemahan-kelemahan dalam pengembangan yang sedang berlangsung, dilakukan dengan memberikan kritik dan saran melalui sebuah instrumen penelitian.

Tahap uji coba produk, dilaksanakan dengan skala terbatas di SDN Taman Baru 1 pada kelas V dengan jumlah anak didik yang 25 orang atau yang disesuaikan kebutuhan. Pada uji coba produk ini anak didik diberikan lembaran angket untuk mengetahui respons, penilaian anak didik terhadap mobile learning berbasis android sistem peredaran darah serta soal untuk melihat apakah ada perbedaan pada pemahaman anak didik terhadap materi sistem peredaran darah setelah menggunakan media mobile learning berbasis android ini.

Teknik pengumpulan data digunakan untuk mengumpulkan data pada penelitian ini adalah: (1) wawancara tidak terstruktur, (2) observasi tidak terstruktur (3) lembar kuisioner, Pembuatan kuesioner ini digunakan pada tahapan analisis kebutuhan. (4) Lembar angket, yang diserahkan kepada ahli media dan ahli materi untuk menghasilkan perkiraan dan saran atau masukan sebagai dasar revisi produk agar hasil temuan penelitian dapat digunakan untuk menentukan kelayakan produk. (5) Tes, untuk mengukur sejauh mana pemahaman materi anak didik. (6) Dokumentasi digunakan untuk melihat catatan atau file yang dibuat selama penelitian.

Tabel 1. Kisi-kisi Instrumen Kuesioner Analisis Kebutuhan

\begin{tabular}{|l|l|}
\hline \multicolumn{1}{|c|}{ Kriteria } & \multicolumn{1}{|c|}{ Indikator } \\
\hline \multirow{2}{*}{$\begin{array}{l}\text { Tipe smartphone } \\
\text { yang dimiliki }\end{array}$} & Kepemilikan smartphone \\
\cline { 2 - 3 } $\begin{array}{l}\text { Penggunaan } \\
\text { smartphone }\end{array}$ & $\begin{array}{l}\text { Awal smartphone } \\
\text { smartphone }\end{array}$ \\
\cline { 2 - 2 } & $\begin{array}{l}\text { Durasi penggunaan } \\
\text { smartphone perhari }\end{array}$ \\
\hline $\begin{array}{l}\text { Pemanfaatan } \\
\text { smartphone }\end{array}$ & $\begin{array}{l}\text { Keperluan dalam } \\
\text { menggunakan smartphone }\end{array}$ \\
\cline { 2 - 2 } & $\begin{array}{l}\text { Aplikasi yang } \\
\text { digunakan }\end{array}$ \\
\cline { 2 - 2 } & $\begin{array}{l}\text { Penggunaan aplikasi media } \\
\text { pembelajaran }\end{array}$ \\
\hline
\end{tabular}




\begin{tabular}{|l|lr|}
\hline & $\begin{array}{l}\text { Minat terhadap aplikasi media } \\
\text { pembelajaran }\end{array}$ \\
\cline { 2 - 3 } & $\begin{array}{l}\text { Penggunaan } \\
\text { disekolah }\end{array}$ & smartphone \\
\cline { 2 - 3 } & $\begin{array}{l}\text { Pemanfaatan } \\
\text { disekolah }\end{array}$ & smartphone \\
\hline
\end{tabular}

Tabel 2. Kisi-kisi Instrumen Angket Uji Ahli Media

\begin{tabular}{|c|c|}
\hline Kriteria & Indikator \\
\hline \multirow[t]{3}{*}{ Kualitas Tampilan } & $\begin{array}{l}\text { Icon/tombol memudahkan } \\
\text { dalam penggunaan aplikasi } \\
\text { android }\end{array}$ \\
\hline & $\begin{array}{ll}\text { Penempatan } & \text { tombol } \\
\text { proporsional } & \end{array}$ \\
\hline & $\begin{array}{l}\text { Proses loading aplikasi media } \\
\text { (tidak terjadi hank atau crash) }\end{array}$ \\
\hline \multirow{3}{*}{$\begin{array}{l}\text { Rekayasa } \\
\text { Perangkat Lunak }\end{array}$} & Kemudahan fungsi drag \\
\hline & Kemudahan fungsi touch \\
\hline & $\begin{array}{l}\text { Kemudahan pengoprasian } \\
\text { fungsi tombol }\end{array}$ \\
\hline \multirow[t]{5}{*}{ Interface } & $\begin{array}{l}\text { Antarmuka pada media memilki } \\
\text { tata letak yang baik }\end{array}$ \\
\hline & Ketepatan pemilihan warna \\
\hline & Ketepatan pemilihan huruf \\
\hline & $\begin{array}{l}\text { Ketepatan pemilihan ukuran } \\
\text { huruf }\end{array}$ \\
\hline & $\begin{array}{l}\text { Format dan resolusi gambar } \\
\text { yang disajikan sesuai dengan } \\
\text { tampilan media }\end{array}$ \\
\hline \multirow[t]{3}{*}{ Maintable } & $\begin{array}{l}\text { Aplikasi mudah di-memasang } \\
\text { dari sistem android }\end{array}$ \\
\hline & $\begin{array}{lcr}\begin{array}{l}\text { Aplikasi } \\
\text { unmemasang } \\
\text { android }\end{array} & \begin{array}{c}\text { mudah } \\
\text { dari }\end{array} & \begin{array}{r}\text { di- } \\
\text { sistem }\end{array} \\
\end{array}$ \\
\hline & $\begin{array}{l}\text { 1) File apk. Mudah ditransfer } \\
\text { dari satu smartphone ke } \\
\text { smartphone lainnya }\end{array}$ \\
\hline \multirow[t]{3}{*}{ Compability } & 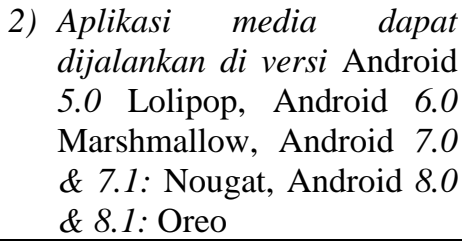 \\
\hline & $\begin{array}{l}\text { Aplikasi media dapat dijalankan } \\
\text { di semua resolusi layer }\end{array}$ \\
\hline & $\begin{array}{l}\text { Aplikasi media dapat mudah } \\
\text { digunakan oleh para pengguna }\end{array}$ \\
\hline
\end{tabular}

Sumber: (Oktaviani, 2015:58-59) dengan modifikasi

Tabel 3. Kisi-kisi Instrumen Angket Uji Ahli Materi

\begin{tabular}{|l|l|}
\hline \multicolumn{1}{|c|}{ Kriteria } & \multicolumn{1}{|c|}{ Indikator } \\
\hline \multirow{4}{*}{$\begin{array}{l}\text { 1. Aspek Kelayakan } \\
\text { Isi }\end{array}$} & $\begin{array}{l}\text { A. Kesesuaian Materi } \\
\text { dengan SK dan KD }\end{array}$ \\
\cline { 3 - 3 } & B. Keakuratan Materi \\
\cline { 2 - 3 } & C. Kemutakhiran Materi \\
\cline { 2 - 2 } & $\begin{array}{l}\text { D. Mendorong } \\
\text { Keingintahuan }\end{array}$ \\
\hline \multirow{2}{*}{$\begin{array}{l}\text { 2. Aspek Kelayakan } \\
\text { Penyajian }\end{array}$} & A. Teknik Penyajian \\
\cline { 2 - 3 } & B. Pendukung Penyajian \\
\cline { 2 - 3 } & C. Penyajian Pembelajaran \\
\cline { 2 - 3 } & $\begin{array}{l}\text { D. Koherensi dan } \\
\text { Keruntutan Alur Pikir }\end{array}$ \\
\hline $\begin{array}{l}\text { 3. Aspek Penilaian } \\
\text { Kontekstual }\end{array}$ & A. Hakikat Kontekstual \\
\hline
\end{tabular}

Sumber: BSNP (Urip Purwono, 2008); DEPDIKNAS (2002) yang dimodifikasi

Tabel 4. Kisi-kisi Instrumen Angket Respons Anak didik

\begin{tabular}{|c|c|}
\hline Kriteria & Indikator \\
\hline \multirow[t]{4}{*}{ Tampilan Media } & Kejelasan teks \\
\hline & Kejelasan gambar \\
\hline & Kemenarikan gambar \\
\hline & Kesesuaian dengan materi \\
\hline \multirow{7}{*}{ Penyajian materi } & Penyajian materi \\
\hline & $\begin{array}{l}\text { Memudahkan pemahaman } \\
\text { materi }\end{array}$ \\
\hline & $\begin{array}{ll}\text { Ketepatan } & \text { sistematika } \\
\text { penyajian materi }\end{array}$ \\
\hline & Kejelasan kalimat \\
\hline & $\begin{array}{lll}\begin{array}{l}\text { Kejelasan } \\
\text { lambang }\end{array} & \text { simbol } & \text { dan } \\
\end{array}$ \\
\hline & Kejelasan istilah \\
\hline & $\begin{array}{l}\text { Kesesuaian contoh dengan } \\
\text { materi }\end{array}$ \\
\hline \multirow[t]{3}{*}{ Manfaat } & Kemudahan belajar \\
\hline & $\begin{array}{l}\text { Ketertarikan menggunakan } \\
\text { media }\end{array}$ \\
\hline & Sumber pengetahuan \\
\hline
\end{tabular}

Tabel 5. Kisi-kisi Instrumen Pretest dan Posttest

Pemahaman Konsep Sistem Peredaran Darah

\begin{tabular}{|c|c|c|c|}
\hline $\begin{array}{c}\text { Kompetensi } \\
\text { Inti }\end{array}$ & $\begin{array}{c}\text { Kompetensi } \\
\text { Dasar }\end{array}$ & Materi & Indikator \\
\hline Memahami & 6. Menjelaskan & Organ & Melengka \\
pengetahuan & organ & Peredar & pi organ \\
faktual, & peredaran & an & peredaran \\
darah dan \\
konseptual, \\
darah dan & Darah & fungsinya \\
dan & $\begin{array}{c}\text { fungsinya pada } \\
\text { hewan dan }\end{array}$ & & pada \\
metakognitif & manusia serta & & manusia \\
\hline
\end{tabular}




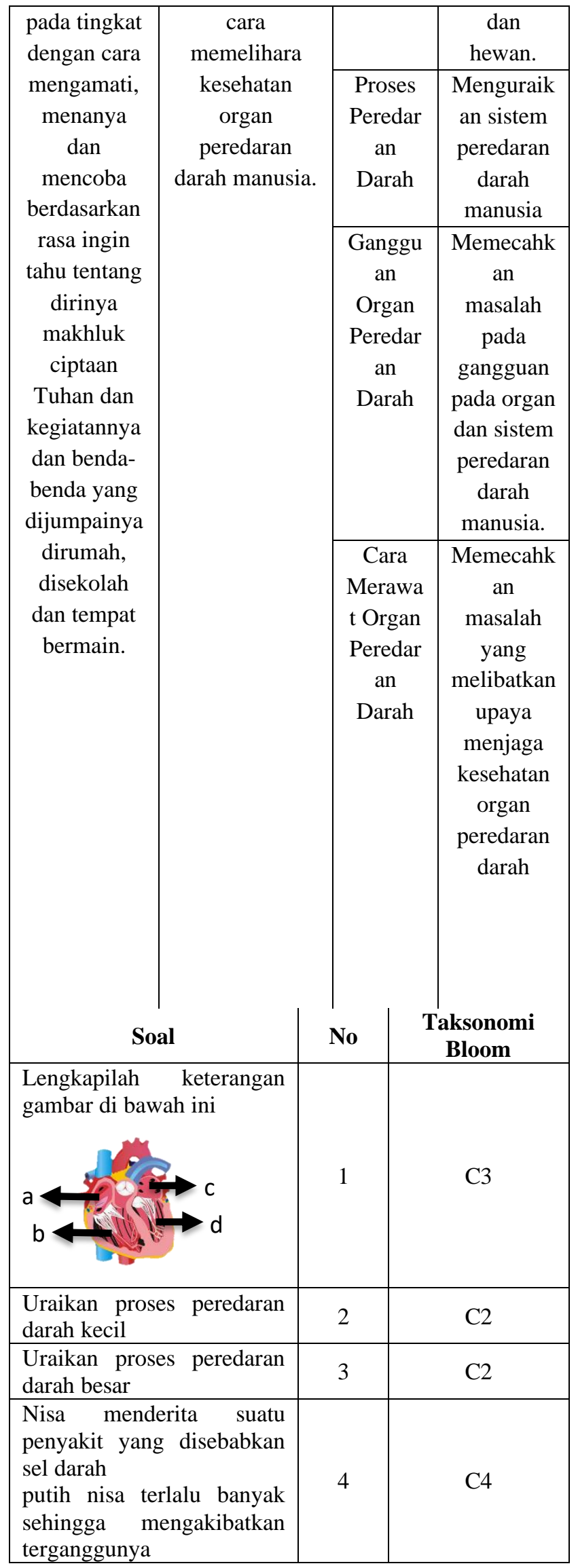

\begin{tabular}{|c|c|c|}
\hline $\begin{array}{l}\text { keseimbangan komposisi } \\
\text { darah nisa, apakah penyakit } \\
\text { yang diderita nisa? }\end{array}$ & & \\
\hline $\begin{array}{l}\text { Ketika kita ingin menjaga } \\
\text { dan merawat organ } \\
\text { peredaran darah kita agar } \\
\text { tetap sehat, apa saja yang } \\
\text { harus kita lakukan? }\end{array}$ & 5 & C5 \\
\hline
\end{tabular}

Teknik analisis data metode analisis data dilakukan untuk mendapatkan media edukasi yang sesuai dan berkualitas dan memenuhi kriteria validitas. Langkah -langkah dalam anlisis produk yang dikembangkan sebagai berikut :

\section{1) Angket Validasi Ahli}

Adapun rumusan yang digunakan untuk menghitung hasil uji ahli dengan menggunakan teknik pengolahan data menurut (Purwanto, 2017:207).

$$
\text { NP : } \frac{R}{\mathrm{SM}} \times 100 \%
$$

Keterangan :

NP : Nilai persentase kelayakan yang diinginkan

R : Skor Mentah

SM : Skor maksimal

Tabel 6. Kriteria Pemberian Skor

\begin{tabular}{|c|c|}
\hline Keterangan & Skor \\
\hline Sangat layak & 5 \\
\hline Layak & 4 \\
\hline Cukup layak & 3 \\
\hline Kurang layak & 2 \\
\hline Sangat tidak layak & 1 \\
\hline
\end{tabular}

(Dimodifikasi dari Arikunto, 2012:35)

Tabel 7. Kriteria Kategori Interpretasi

\begin{tabular}{|c|c|}
\hline Skor (\%) & Keteraangan \\
\hline $0-20$ & Sangat tidak layak \\
\hline $21-40$ & Kurang layak \\
\hline $41-60$ & Cukup layak \\
\hline $61-80$ & Layak \\
\hline $81-100$ & Sangat layak \\
\hline
\end{tabular}

(Dimodifikasi dari Purwanto, 2017:103) 


\section{2) Angket Respons Anak Didik}

Pada angket respon peserta didik digunakan skala Guttman Ya dan Tidak. Penilaiannya akan dijabarkan sebagai berikut:

$$
\mathrm{NP}: \frac{n}{\mathrm{~N}} \times 100 \%
$$

Keterangan :

NP : Persentase respons anak didik setiap indikator

$\mathrm{n} \quad$ : Jumlah skor perolehan anak didik setiap indikator

$\mathrm{N}$ : Jumlah skor total untuk setiap indikator

Tabel 8. Kriteria Pemberian Skor Respons dan Anak didik

\begin{tabular}{|c|c|}
\hline Jawaban & Skor \\
\hline Ya & 1 \\
\hline Tidak & 0 \\
\hline
\end{tabular}

(Dimodifikasi dari Sugiyono, 2014:139)

Tabel 9. Kriteria Kategori Interpretasi

\begin{tabular}{|c|c|}
\hline Persentase Penilaian (\%) & Interpretasi \\
\hline$<20 \%$ & Sangat Kurang \\
\hline $21 \%-40 \%$ & Kurang \\
\hline $41 \%-60 \%$ & Cukup \\
\hline $61 \%-80 \%$ & Baik \\
\hline $81 \%-100 \%$ & Sangat Baik \\
\hline
\end{tabular}

(Dimodifikasi dari Purwanto, 2017:103)

3) Tes Pemahaman

Tabel 10. Skor Penilaian Pemahaman Konsep

\begin{tabular}{|l|l|}
\hline \multicolumn{1}{|c|}{ Skor } & \multicolumn{2}{|c|}{ Deskripsi } \\
\hline Superior & - Jawaban dari tugas sangat \\
& spesifik. \\
& - Informasi yang diajukan sahih \\
& dan lengkap serta \\
& memperlihatkan pemahaman \\
& yang lengkap. \\
& - Jawaban diungkapkan dengan \\
& tulisan yang lancar \\
\hline 3 & - Jawabannya memberi jawaban \\
Memuaskan & untuk tugas itu. \\
\hline
\end{tabular}

\begin{tabular}{|c|c|}
\hline $\begin{array}{l}\text { dengan sedikit } \\
\text { kekurangan }\end{array}$ & 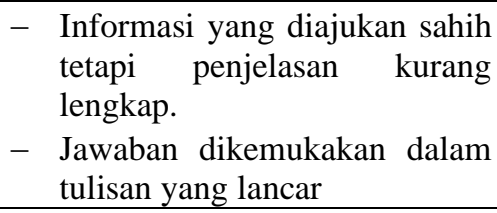 \\
\hline $\begin{array}{l}2 \\
\text { Cukup } \\
\text { memuaskan } \\
\text { dengan banyak } \\
\text { kekurangan }\end{array}$ & $\begin{array}{ll}\text { - Jawaban kurang menjawab } \\
\text { tugas yang diberikan } \\
\text { - } \text { Informasi yang diajukan } \\
\text { kurang sahih dan penjelasan } \\
\text { kurang lengkap. } \\
\text { - } \text { Jawaban dikemukakan dalam } \\
\text { tulisan yang kurang lancar }\end{array}$ \\
\hline $\begin{array}{l}1 \\
\text { Tidak } \\
\text { memuaskan }\end{array}$ & $\begin{array}{l}\text { - Jawaban tidak menjawab tugas } \\
\text { yang diberikan. } \\
\text { - } \text { Informasi yang diajukan tidak } \\
\text { lengkap dan tidak sahih. } \\
\text { - } \text { Jawaban dikemukakan dalam } \\
\text { tulisan yang tidak lancar }\end{array}$ \\
\hline
\end{tabular}

(Dimodifikasi dari Lestari, 2017:31)

Untuk menghitung data tentang pemahaman konsep anak didik setelah menggunakan media mobile learning berbasis android dapat diketahui dari hasil posttest dan pretest. Hasil ini dihitung menggunakan rumus $\mathrm{N}$-gain dengan rata-rata gain.

$$
\mathrm{g}: \frac{\mathrm{S} \text { post-S pre }}{\mathrm{S} \text { maks-S pre }}
$$

keterangan :

$$
\begin{array}{ll}
\mathrm{g} & \text { : rata-rata gain } \\
\text { S post } & \text { : rata-rata posttest } \\
\text { S pre } & \text { : rata-rata pretest } \\
\text { S maks } & \text { : skor maksimal }
\end{array}
$$

Nilai yang diperoleh kemudian di interpretasikan sesuai dengan kriteria dibawah ini:

Tabel 11. Kriteria Kategori Interpretasi

\begin{tabular}{|c|c|}
\hline Rentang Skor & Kriteria \\
\hline (N-gain $) \geq 0,7$ & Tinggi \\
\hline $0,7>(\mathrm{N}$-gain $) \geq 0,3$ & Sedang \\
\hline (N-gain $)<0,3$ & Rendah \\
\hline
\end{tabular}

(Dimodifikasi dari Nurhairunnisah \& Sujarwo, 2018:1) 


\section{HASIL DAN PEMBAHASAN}

Pada tahap awal pembuatan media mobile learning berbasis android ini dimulai dengan tahap analisis masalah. Tahapan ini meliputi kegiatan analisis kurikulum, analisis materi dan analisis kebutuhan. Analisis kebutuhan dilakukan dengan observasi, wawancara tidak terstruktur dengan wali kelas, menyebarkan kuisioner serta melakukan pretest kepada anak didik kelas V di SDN Taman Baru 1. Hasil observasi dan wawancara tidak terstruktur di SDN Taman Baru 1 hanya memakai buku paket serta LKS yang disediakan pemerintah juga sesekali menggunakan media gambar yang dicetak dan juga belum dilengkapi dengan alat-alat penunjang untuk media pembelajaran seperti proyektor. Untuk pemahaman anak didik beberapa anak didik sudah memahami materi akan tetapi sebagiannya masih ada yang kurang memahami materi sistem peredaran darah. Berdasarkan kuisioner dan pretest memang belum seluruhnya memahami materi sistem peredaran darah hal ini terlihat dari rentan nilai yang diperoleh anak didik pada pretest yakni 35-70. Sedangkan untuk kepemilikan smarphone 20 dari 25 anak didik memiliki smarphone sendiri dan 5 anak didik lainnya masih ikut menggunakan smarphone milik orang tuanya.

Analisis kurikulum dilakukan dengan mendeskripsikan Kompetensi Inti (KI) dan Kompetensi Dasar (KD) menjadi indikator pembelajaran. Aspek tersebut perlu diidentifikasi karena setiap aspek kompetensi dasar membutuhkan jenis materi yang berbeda dalam proses belajar (Amri \& Ahmadi, 2010:63). Analisis materi dilakukan dengan menyesuaikan materi dengan kompetensi dasar yang termuat pada kurikulum 2013. Tujuan dilakukan analisis materi yaitu agar materi dalam media pembelajaran mobile learning berbasis android sesuai dengan kompetensi dasar yang terdapat pada materi Sistem Peredaran Darah yang terdapat di tema 4.

Tahap pengumpulan data dilakukan dengan cara studi literatur dan studi lapangan. Studi literatur diawali dengan penetapan $\mathrm{KD}$ yaitu 3.4 Menjelaskan organ peredaran darah dan fungsinya pada hewan dan manusia serta cara memelihara kesehatan organ peredran darah manusia. dan materi sistem peredaran darah pada kurikulum 2013. Referensi yang digunakan pada analisis materi yaitu buku Tema 4 Sehat Itu Penting untuk SD/MI Kelas 5 Semester Ganjil dan IPA Asik, Mudah dan Menyenangkan 5A. Penerbit Grasindo dan Kandel. Sedangkan untuk memperoleh data lapangan diambil dengan studi lapangan yakni observasi pembelajaran, wawancara tidak terstruktur pada guru kelas V SDN Taman Baru 1, penyebaran angkat dan pretest pada anak didik kelas V SDN Taman Baru 1.

Pada awal pengembangan dan sebelum uji coba produk, peneliti membuat desain awal produk Mobile learning berbasis Android Sistem Peredaran Darah untuk sekolah dasar. Berikut adalah gambaran dari Mobile learning berbasis Android Sistem Peredaran Darah:

a. Media : Multimedia / Media Audiovisual

b. Ukuran Download : 94,75 MB

c. Versi : 2508.0

d. OS : Minimal Android 5.0 (Lolipop)

e. Isi : Menu utama, Profil, Kompetensi, Sumber, Setiap bagian sub materi, VIRASI (Video 
Pembelajaran Animasi), RATERI (Rangkuman

Materi), MALATI (Mari Berlatih)

f. Materi : Sistem Peredaran Darah

Pada setiap VIRASI di aplikasi SIRERA ini berisikan penjelasan tentang materi sistem peredaran darah yang dibagi 3 sub materi. Penjelasan pada VIRASI ini dikemas dalam bentuk semenarik mungkin dengan menggunakan tokoh animasi untuk menarik minat anak didik. Di dalam RATERI berisikan ringkasan materi yang dikemas dengan semenarik mungkin dengan disisipkannya gambar-gambar yang berkaitan dengan materi yang ada. Sedangkan didalam MALATI berisikan Latihan soal yang dilengkapi juga dengan pembahasannya. Berikut ini adalah contoh desain produk Mobile learning berbasis Android Sistem Peredaran Darah.
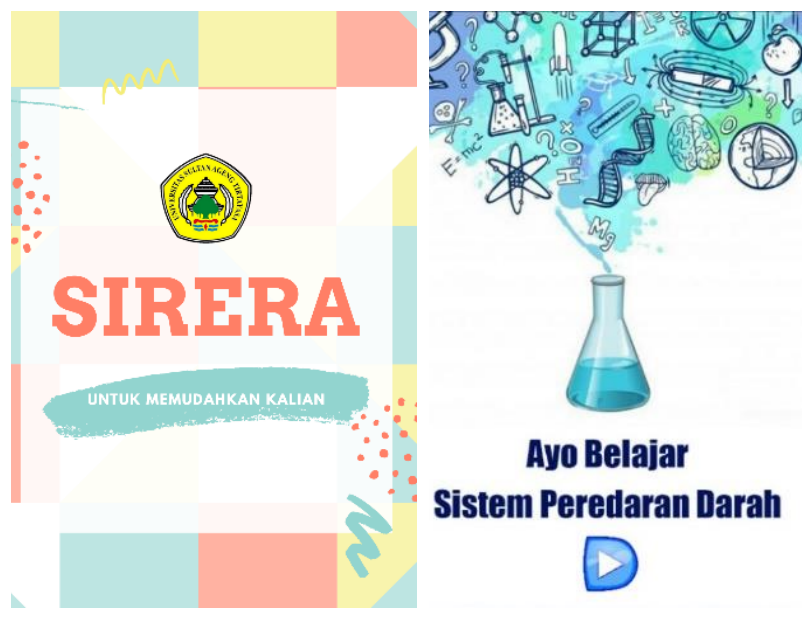
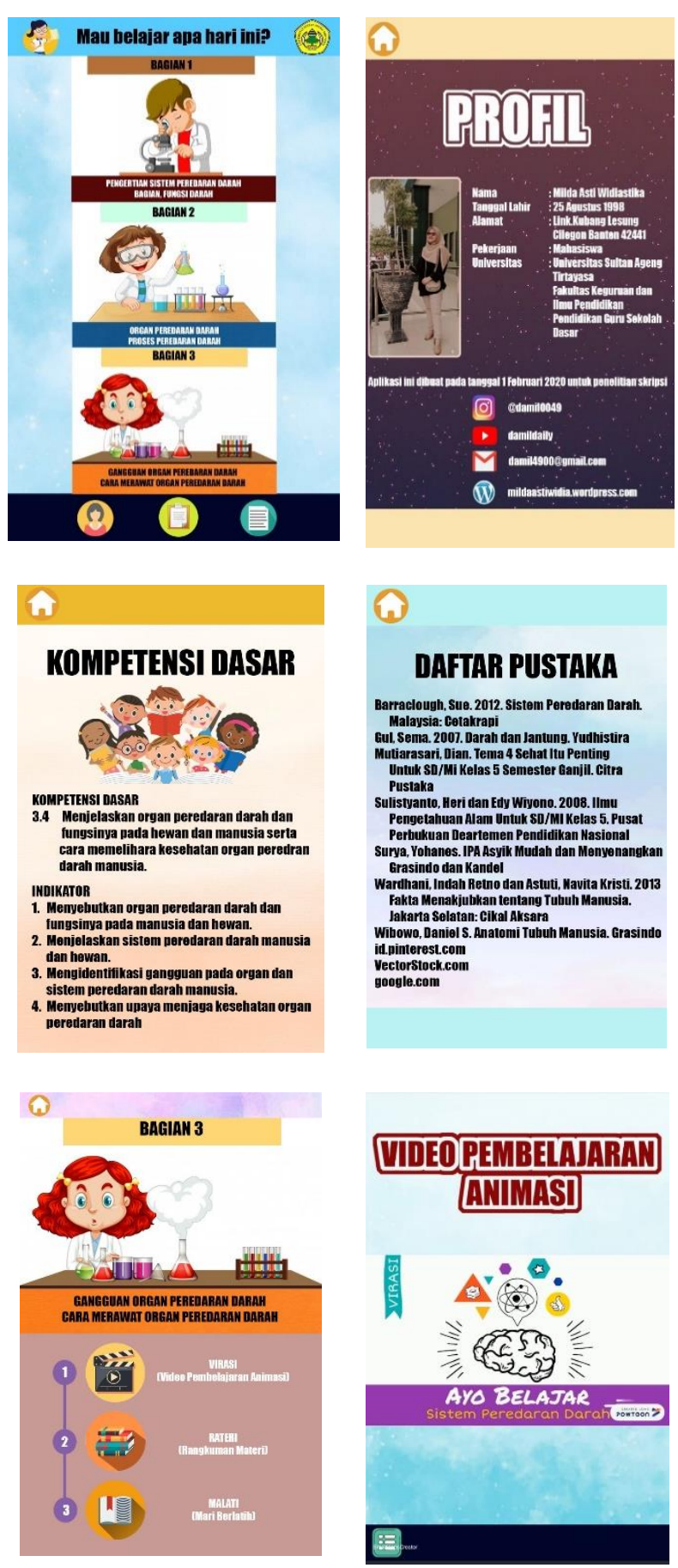

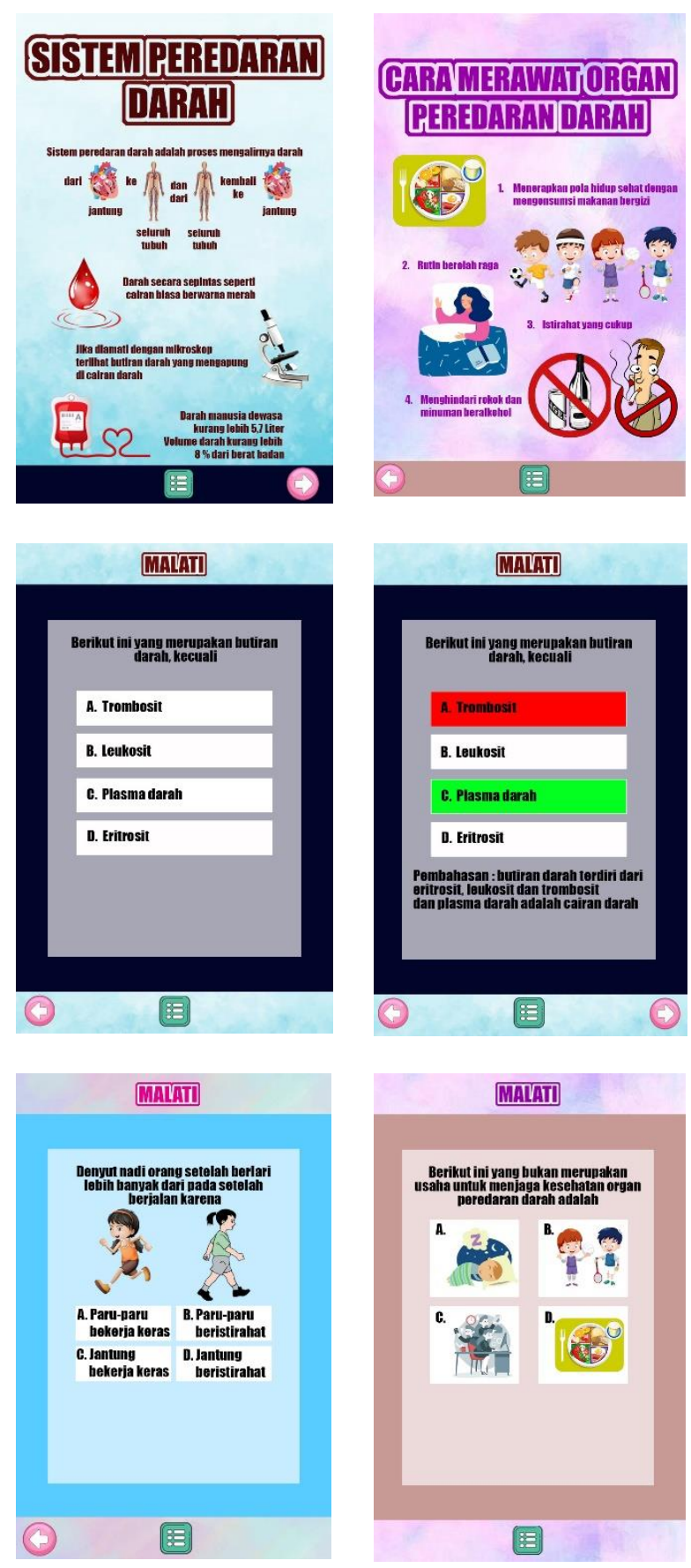

Gambar 1. Tampilan Mobile learning berbasis Android Sistem Peredaran Darah

Setelah media Mobile learning berbasis android Sistem Peredaran Darah selesai dibuat, dilanjutkan dengan melakukan penilaian oleh ahli untuk me-review media yang dikembangkan. Uji ahli dilakukan dengan memberikan lembar penilaian kepada 4 orang dosen ahli, berikut ini merupakan penjabaran hasil dari validasi mobile learning berbasis android pada materi Sistem Peredaran Darah, yang dilakukan oleh para ahli. Uji ahli untuk validasi bahan ajar ini adalah sebagai berikut:

Tabel 12. Hasil Validasi Tim Ahli Media

\begin{tabular}{|c|c|c|c|c|}
\hline \multirow[t]{2}{*}{ No } & \multirow{2}{*}{$\begin{array}{c}\text { Aspek } \\
\text { Penilaian }\end{array}$} & \multicolumn{2}{|c|}{ Ahli Media } & \multirow{2}{*}{$\begin{array}{c}\text { NP(\%) } \\
\text { Total }\end{array}$} \\
\hline & & Ahli I & Ahli II & \\
\hline 1 & $\begin{array}{l}\text { Kualitas } \\
\text { Tampilan }\end{array}$ & 10 & 12 & $\begin{array}{c}\frac{22}{30} \times 100 \% \\
=73 \%\end{array}$ \\
\hline 2 & $\begin{array}{c}\text { Rekayasa } \\
\text { Perangkat } \\
\text { Lunak }\end{array}$ & 8 & 9 & $\begin{array}{c}\frac{17}{20} \times 100 \% \\
=85 \%\end{array}$ \\
\hline 3 & Interface & 23 & 23 & $\begin{array}{c}\frac{46}{50} \times 100 \% \\
=92 \%\end{array}$ \\
\hline 4 & Maintabel & 12 & 15 & $\begin{array}{c}\frac{27}{30} \times 100 \% \\
=90 \%\end{array}$ \\
\hline 5 & Compability & 12 & 14 & $\begin{array}{c}\frac{26}{30} \times 100 \% \\
=87 \%\end{array}$ \\
\hline & Jumlah & 65 & 73 & 138 \\
\hline & NP (\%) & $\begin{array}{c}\frac{65}{80} \times 100 \% \\
=81,2 \%\end{array}$ & $\begin{array}{c}\frac{73}{80} \times 100 \% \\
=91,2 \%\end{array}$ & 86,2 \\
\hline$\sum$ & Rata - rata & & & \\
\hline
\end{tabular}

Berdasarkan tabel diatas menunjukkan bahwa dari ahli media I diperoleh jumlah 65 dari 16 pernyataan dengan persentase nilai $81,2 \%$. Adapun dari ahli media II diperoleh jumlah 73 dari 16 pernyataan dengan persentase nilai $91,2 \%$. Hasil jumlah keseluruhan validasi 2 ahli yaitu 138 dengan nilai rata-rata keseluruhan yaitu $86,2 \%$ dengan kategori "Sangat Layak" sehingga dapat digunakan (Purwanto, 2017:103).

Tabel 13. Hasil Validasi Tim Ahli Materi 


\begin{tabular}{|c|c|c|c|c|}
\hline \multirow[t]{2}{*}{ No } & \multirow{2}{*}{$\begin{array}{c}\text { Aspek } \\
\text { Penilaian }\end{array}$} & \multicolumn{2}{|c|}{ Ahli Materi } & \multirow{2}{*}{$\begin{array}{c}\text { NP(\%) } \\
\text { Total }\end{array}$} \\
\hline & & Ahli I & Ahli II & \\
\hline 1 & $\begin{array}{l}\text { Kelayakan } \\
\text { Isi }\end{array}$ & 72 & 49 & $\begin{array}{c}\frac{121}{150} \times 100 \% \\
=80,7 \%\end{array}$ \\
\hline 2 & $\begin{array}{l}\text { Kelayakan } \\
\text { Penyajian }\end{array}$ & 46 & 36 & $\begin{array}{c}\frac{82}{100} \times 100 \% \\
=82 \%\end{array}$ \\
\hline 3 & $\begin{array}{c}\text { Penilaian } \\
\text { Kontekstual }\end{array}$ & 10 & 6 & $\begin{array}{c}\frac{16}{20} \times 100 \% \\
=80 \%\end{array}$ \\
\hline & Jumlah & 128 & 91 & 219 \\
\hline & NP (\%) & $\begin{array}{c}\frac{128}{135} \times 100 \% \\
=94,8 \%\end{array}$ & $\begin{array}{c}\frac{91}{135} \times 100 \% \\
=67,4 \%\end{array}$ & \\
\hline \multicolumn{2}{|c|}{$\sum$ Rata - rata } & \multicolumn{2}{|c|}{$81,1 \%$} & 81,1 \\
\hline
\end{tabular}

Berdasarkan tabel diatas menunjukkan bahwa dari ahli materi I diperoleh jumlah 128 dari 27 pernyataan dengan persentase nilai $94,8 \%$. Adapun dari ahli materi II diperoleh jumlah 91 dari 27 pernyataan dengan persentase nilai $67,4 \%$. Hasil jumlah keseluruhan validasi 2 ahli yaitu 219 dengan nilai rata-rata keseluruhan yaitu $81,1 \%$ dengan kategori "Sangat Layak" sehingga dapat digunakan (Purwanto, 2017:103).

Selanjutnya setelah dilakukan uji coba terbatas akan menghasilkan produk akhir berupa media mobile learning berbasis android sebagai media pembelajaran untuk anak didik kelas V SD pada mata pelajaran dengan materi Sistem Peredaran Darah. Adapun hasil penilaian analisis data pada respons anak didik disajikan pada tabel berikut:

Tabel 14. Data Hasil Respons Anak didik

\begin{tabular}{|c|c|c|c|c|}
\hline \multirow{2}{*}{ Ket } & \multicolumn{3}{|c|}{ Aspek } & \multirow{2}{*}{ Skor } \\
\cline { 2 - 4 } & Media & Materi & Manfaat & \\
\hline $\begin{array}{c}\text { Total } \\
\text { Skor }\end{array}$ & 163 & 162 & 94 & $\mathbf{4 1 9}$ \\
\hline $\begin{array}{c}\text { Nilai } \\
\text { Akhir } \\
(\%)\end{array}$ & 81,5 & 81 & 94 & $\mathbf{8 3 , 8} \%$ \\
\hline
\end{tabular}

\begin{tabular}{|c|c|}
\hline Rata-rata & \\
\hline Kategori & $\begin{array}{c}\text { Sangat } \\
\text { Baik }\end{array}$ \\
\hline
\end{tabular}

Berdasarkan tabel tersebut, hasil analisis data respons anak didik terhadap media mobile learning berbasis android memperoleh nilai akhir rata-rata sebesar 83,8 \% yang masuk dalam kategori "Sangat Baik". Hal ini dikarenakan media tersebut baik dan mudah digunakan pada anak didik kelas V.

Untuk mengetahui kemampuan pemahaman konsep IPA anak didik setelah menggunakan setelah menggunakan media mobile learning berbasis android, digunakan instrumen tes. Tes diberikan terdiri dari dua tahapan yaitu pretest dan posttet.

$$
\begin{gathered}
\frac{\text { S posttest }- \text { S pretest }}{\text { S maksimal }- \text { S pretest }} \\
=\frac{89,6-52,6}{100-52,6} \\
=\frac{37}{47,4} \\
=0,78 \\
=0,8
\end{gathered}
$$

Berdasarkan perhitungan diatas menunjukkan bahwa gain skor yang diperoleh dari hasil rata-rata pretest dan posttest yakni sebesar 0,8 dengan kategori “Tinggi” Dengan demikian penelitian ini telah menunjukkan hasil positif terhadap kemampuan pemahaman konsep anak didik pada materi sistem peredaran darah (Nurhairunnisah \& Sujarwo, 2018:1).

Pada tahap awal yaitu analisis masalah dilakukan dengan analisis kebutuhan, analisis kurikulum dan analisis materi. Selanjutnya 
dilakukan uji ahli oleh 2 tim ahli yaitu, ahli media dan ahli materi dengan masing-masing ahli di validator oleh 2 orang dosen. Validasi dilakukan dengan tujuan apakah produk yang dikembangkan layak untuk digunakan dalam pelajaran IPA di sekolah dasar atau tidak layak untuk digunakan. Hasil validasi media berdasarkan ahli sebagai berikut:

Tabel 15. Rerata Skor Validasi Ahli

\begin{tabular}{|c|c|c|}
\hline Hasil Validasi & Persentase & Kategori \\
\hline $\begin{array}{c}\text { Ahli Desain } \\
\text { Media }\end{array}$ & $86,2 \%$ & Sangat Layak \\
\hline Ahli Materi & $81,1 \%$ & Sangat Layak \\
\hline Rata-Rata Skor & $\mathbf{8 4 \%}$ & Sangat Layak \\
\hline
\end{tabular}

Berdasarkan hasil uji validasi yang telah dilakukan oleh 2 ahli yakni ahli media dan ahli materi, peneliti mendapatkan perolehan rata-rata skor validasi ahli sebesar $84 \%$. Skor tersebut masuk pada kategori "Sangat Layak" berdasarkan standar interpretasi (Purwanto, 2017:103) sehingga media mobile learning berbasis android tersebut dapat digunakan disekolah untuk membantu proses pembelajaran.

Hasil akhir validasi oleh ahli media memperoleh rata-rata persentase nilai akhir sebesar 86,2\% dengan kategori "Sangat Layak". Penilaian yang dilakukan oleh ahli media ditinjau dari 5 aspek, yaitu aspek kualitas tampilan, rekayasa perangkat lunak, interface, mantabel, compability. Hasil skor rata-rata nilai ahli media belum mencapai sempurna dilihat dari masih kekurangan skor $13,8 \%$ untuk mencapai skor sempurna. Hal ini dikarenakan media yang dikembangkan masih terdapat beberapa perbaikan yang disarankan oleh para ahli validasi pada penambahan logo UNTIRTA pada aplikasi, pemilihan ikon next, back, home, dan menu untuk dijadikan tombol. Hal tersebut sudah diperbaiki oleh peneliti sehingga hal-hal yang sebelumnya belum sesuai kriteria sudah terpenuhi dan mencapai kriteria yang ditentukan. Hal ini sesuai dengan pernyataan (Rohinah, 2016:68) menyatakan bahwa kemudahan dalam mengakses aplikasi membuat anak didik menjadi lebih tertarik dalam mempelajari materi yang disediakan.

Hasil akhir validasi oleh ahli materi memperoleh rata-rata persentase nilai akhir sebesar 81,1\% dengan kategori "Sangat Layak". Penilaian yang dilakukan oleh ahli media ditinjau dari 3 aspek, yaitu aspek kelayakan isi, kelayakan penyajian, penilaian konstektual. Hasil skor ratarata nilai ahli media belum mencapai sempurna dilihat dari masih kekurangan skor $18,9 \%$ untuk mencapai skor sempurna. Hal ini dikarenakan media yang dikembangkan masih terdapat beberapa perbaikan yang disarankan oleh para ahli validasi pada penambahan daftar pustaka, kompetensi, dan penambahan gambar pada bagian MALATI agar lebih menarik perhatian dan minat anak dalam mengerjakannya. Hal tersebut sudah diperbaiki oleh peneliti sehingga hal-hal yang sebelumnya belum sesuai kriteria sudah terpenuhi dan mencapai kriteria yang ditentukan.

Hal ini sesuai dengan pernyataan (Sutikno, 2009:112) pembuatan media pembelajaran harus memiliki ketepatan tujuan pembelajaran dan dukungan terhadap isi materi pelajaran yang sifatnya fakta, prinsip, dan konsep agar lebih mudah dipahami oleh anak didik. Sedangkan 
menurut (Sanjaya, 2012:135) kriteria penyusunan materi dalam pengembangan media yaitu harus sahih atau valid dan menarik minat anak didik. Sahih atau valid artinya materi yang disajikan benar-benar telah sesuai dengan gambar yang digunakan, selain itu penyajian materi media mobile learning berbasis android harus menarik anak didik untuk mempelajarinya lebih lanjut.

Uji coba terbatas dilakukan kepada anak didik kelas V SD Taman Baru 1 dengan jumlah 25 peserta duduk. Proses pembelajaran dilakukan dengan anak didik diberikan file apk kepada anak didik melalui media sosial whatsapp dan kemudian di pasang pada smarphone masing-masing anak didik. Kemudian anak didik diarahkan dalam penggunaan mobile learning berbasis android mulai dari bagian VIRASI, RATERI juga MALATI pada setiap sub materi yang disajikan. Kemudian dilakukan sesi tanya jawab dengan peneliti. Setelah itu peneliti membagikan posttes yang berjumlah 5 soal dan angket yang berisi 20 pernyataan yang terdiri dari 3 aspek yaitu, aspek penyajian media, penyajian materi dan manfaat.

Hasil tes pemahaman konsep anak didik menampakkan adanya peningkatan dalam pemahaman konsep anak didik yang dilihat dari hasil pretest dan posttes yang sudah dilakukan dengan rata-rata nilai sebesar 52,6 dan 89,6. Selain itu peningkatan pemahaman konsep anak didik dapat dilihat dari gain skor yang diperoleh dari rata-rata pretest dan posttest yakni sebesar 0,8 dengan kategori "Tinggi" Dengan demikian penelitian ini telah menunjukkan hasil positif terhadap kemampuan pemahaman konsep anak didik pada materi sistem peredaran darah karena adanya kenaikan di nilai pretest dan posttest yang dilakukan anak didik.

Hal ini sejalan dengan pernyataan (Sudjana and Riyai 2010:2) yang menyatakan bahwa media edukasi akan membuat pengajaran lebih memikat perhatian anak didik sehingga dapat menanamkan motivasi belajar dan juga dapat memberikan materi pengajaran menjadi lebih jelas sehingga anak didik dapat lebih memahami dan membuat anak didik menguasai dan mencapai tujuan pembelajaran. Sedangkan (Purnama, Sesunan, and Ertikanto 2017:71) menyatakan bahwa media pembelajaran yang dilengkapi latihan, tutorial, dan simulasi bisa memudahkan anak didik sehingga dapat menambah dalam pemahaman konsep dan berpikir kritis.

Hasil pengisian angket respons anak didik tersebut diperoleh skor pada masing-masing aspek yaitu, aspek penyajian media memperoleh persentase sebesar $81,5 \%$, aspek penyajian materi dengan persentase $81 \%$, dan aspek manfaat dengan persentase $94 \%$. Dari ketiga aspek hasil persentase tersebut diperoleh rata-rata skor sebesar 83,8\% dengan kategori "Sangat Baik" untuk hasil dari angket respons anak didik.

Penilaian respons anak didik terhadap media mobile learning berbasis android pada aspek penyajian media memperoleh persentase sebesar 81,5\% termasuk dalam kategori "Sangat Baik". Hal ini sesuai dengan pemaparan (Susilana and Cepi 2007:187) bahwa anak didik cenderung lebih menyukai hal menarik semacam warna memikat, gambar divisualisasikan dalam bentuk kartun atau animasi menarik sehingga dapat meningkatkan hasil belajar. 
Penilaian respons anak didik terhadap media mobile learning berbasis android pada aspek penyajian materi memperoleh persentase sebesar $81 \%$ termasuk dalam kategori "Sangat Baik". Hal ini sesuai dengan pemaparan (Sanjaya 2012:) kriteria penyusunan materi dalam pengembangan media yaitu harus sahih atau valid dan menarik minat. Sahih atau valid artinya materi yang disajikan harus benar-benar telah sesuai dengan sumber yang digunakan sehingga membantu pemahaman anak didik.

Penilaian respons anak didik terhadap media mobile learning berbasis android pada aspek manfaat memperoleh persentase sebesar 94\% termasuk dalam kategori "Sangat Baik". Hal ini sesuai pemaparan (Arsyad 2014:21-25) bahwa media pembelajaran harus mempunyai manfaat bagi penggunanya, seperti dapat melibatkan anak didik dalam proses pembelajaran yang berlangsung nantinya selain itu juga dapat mendorong rasa ingin tahu dan sikap kreatif anak didik.

\section{SIMPULAN}

Berdasarkan hasil penelitian dan pembahasan, dapat disimpulkan bahwa:

1. Kelayakan media mobile learning berbasis android sebagai media penunjang pembelajaran untuk anak didik sekolah dasar kelas 5 konsep Sistem Peredaran Darah diperoleh dari hasil validasi tim ahli yakni ahli media dan ahli materi. Hasil penilaian ahli media memperoleh rata-rata skor $86,2 \%$ yang sesuai dengan kategori "Sangat Layak". Hasil penilaian ahli materi memperoleh rata-rata (Sudjana and Riyai 2010)skor $81.1 \%$ yang sesuai dengan kategori "Sangat Layak". Bedasarkan hasil tersebut, produk akhir yang berupa media mobile learning berbasis android pada materi sistem peredaran darah yang dihasilkan layak digunakan untuk kegiatan pendidikan anak didik kelas V SD.

2. Pemahaman konsep anak didik setelah menggunakan media Mobile learning Berbasis Android pada mata pelajaran IPA konsep Sistem Peredaran Darah didapatkan dari hasil skor pretest dan posttest yang dihitung yakni sebesar 0,8 dengan kategori "Tinggi” Dengan demikian penelitian ini telah menunjukkan hasil positif terhadap kemampuan pemahaman konsep anak didik pada materi sistem peredaran darah.

3. Respon anak didik terhadap penggunaan media pembelajaran berupa Mobile learning Berbasis Android sebagai media penunjang pembelajaran. Pada uji coba produk dengan rata-rata skor $83,8 \%$ dengan kategori "Sangat Baik".

\section{DAFTAR PUSTAKA}

Amri, Sofan, and Lif Khoirul Ahmadi. 2010. Jakarta Pustakaraya Proses Pembelajaran Inovatif Dan Kreatif Dalam Kelas.

Arikunto, Suharsimi. 2012. Rineka Cipta Prosedur Penelitian: Suatu Pendekatan Praktik (Edisi Revisi).

Arsyad, Azhar. 2014. Media Pembelajaran. Jakarta: Raja Grafindo Persada.

Darmawan, Deni. 2011. Teknologi Pembelajaran. Bandung: PT Remaja Rosdakarya.

Daryanto. 2010. Media Pembelajaran. Yogyakarta: Gava Media.

Depdiknas. 2006. "Panduan Penyusunan Kurikulum Tingkat Satuan Pendidikan." 
Jakarta: BNSP Depdiknas.

Istiyanto, Jasi Eko. 2013. Pemrograman Smartphone Menggunakan SDK Android Dan Hacking Android. Pertama. Yogyakarta: Graha Ilmu.

Jamaludin, Ujang, and Reza Rachmatullah. 2018. Pembelajaran Pendidikan IPS Teori Konsep Dan Aplikasi Bagi Guru Dan Mahasiswa. Bekasi: CV Nurani.

Lee, Wei-Meng. 2012. Engineering Beginning Android ${ }^{T M}$ Application Development.

Lestari, Dyah. 2017. Pengembangan Media Pembelajaran Flap Book Pada Materi Sifat Sifat Bangunan Datar Kelas V Terhadap Pemahaman Konsep Matematis Siswa Sekolah Dasar. Serang: Universitas Sultan Ageng Tirtayasa.

Nurhairunnisah, Nurhairunnisah, and Sujarwo Sujarwo. 2018. "Bahan Ajar Interaktif Untuk Meningkatkan Pemahaman Konsep Matematika Pada Siswa SMA Kelas X." Jurnal Inovasi Teknologi Pendidikan.

O'Malley, C et al. 2005. "Guidelines for Learning/Teaching/Tutoring in a Mobile Environment." MOBIlearn.

Oktaviani, Gian Dwi. 2015. Pengembangan Media Pembelajaran Berbasis Android Dalam Bentuk Digital Untuk Mata Pelajaran Akutansi Perusahaan Jasa Di Kelas XI MAN 1 Yogyakarta Tahun Ajaran 2014/2015. Yogyakarta: Jurusan Pendidikan Akuntansi. Fakultas Ekonomi. Universitas Negeri Yogyakarta.

Purnama, R., F. Sesunan, and C. Ertikanto. 2017. "Pengembangan Media Pembelajaran Mobile Learning Berbasis Android Sebagai Suplemen Pembelajaran Fisika SMA Pada Materi Usaha Dan Energi." Jurnal Pembelajaran Fisika Universitas Lampung.

Purwanto, Ngalim. 2017. PT Remaja Rosdakarya Prinsip-Prinsip Dan Teknik Evaluasi Pengajaran.

Rohinah, Rohinah. 2016. "Pengembangan Aplikasi Bahan Ajar Pendidikan Agama Islam Berbasis Android Di Sekolah Menengah Atas." Al Athfal: Jurnal Pendidikan Anak.

Sanjaya, Wina. 2012. Media Komunikasi
Pembelajaran. Jakarta: PT Kharisma Putra Utama.

Seng, Ciu Bun. 2011. Android Dasar Pengoperasiann, Optimasi Sampai Modifikasi Full Color. Jasakom.

Sudjana, Nana, and Ahmad Riyai. 2010. Media Pengajaran. Bandung: Sinar Baru Algensindo.

Sugiyono. 2011. Metode Penelitian Pendidikan. Bandung: Alfabeta.

—. 2014. Metode Penelitian Pendidikan Pendekatan Kuantitatif, Kualitatif, Dan $R \& D$. Bandung: Alfabeta.

Susilana, Rudi, and Riyana Cepi. 2007. Media Pembelajaran. Bandung: CV Wacana Prima.

Sutikno, M. Sobry. 2009. Belajar Dan Pembelajaran. Jakarta: PT Elex Media Komputindo.

Sutikno, M. Sobry, and Pupuh Fathurrohman. 2010. Bandung: Refika Aditama Strategi Belajar Mengajar Melalui Penanaman Konsep Umum \& Konsep Islami.

TIM EMS. 2015. Pemograman Android Dalam Sehari. Jakarta: PT Elex Media Komputindo. 